\title{
A Red Data List for the Falkland Islands vascular flora
}

\author{
D. A. Broughton and J. H. McAdam
}

\begin{abstract}
The Falkland Islands are situated in the South Atlantic and have a native flora of 171 vascular plant species. Although a relatively high proportion of the native flora is of conservation concern, this is poorly recognized, both nationally and internationally. Typically, threatened species occur as only a few small, isolated populations, and they are facing increasing pressure from land-use change, particularly agricultural intensification. This paper presents the first national Red Data List for the Falkland Islands, and provides an overview of the
\end{abstract}

23 threatened plants of the archipelago as well as covering another 16 species of relevance to the national conservation strategy. This Red List provides an important first step towards the recognition and conservation of the threatened native flora of the Falkland Islands at both the national and international level.

Keywords Falkland Islands, flora, Red List, threatened plants.

\section{Introduction}

The Falkland Islands are an archipelago of over 700 islands (Fig. 1) situated in the South Atlantic between latitudes $51^{\circ}-53^{\circ} \mathrm{S}$ and longitudes $57^{\circ}-62^{\circ} \mathrm{W}$, and covering an area of $12,173 \mathrm{~km}^{2}$. They are c. $500 \mathrm{~km}$ from the nearest point on mainland South America. The climate is cool temperate oceanic with a mean temperature for January of $9.4^{\circ} \mathrm{C}$ and a mean for July of $2.2^{\circ} \mathrm{C}$ (McAdam, 1985). The main vegetation types are acid grasslands dominated by whitegrass Cortaderia pilosa (d'Urv.) Hack. and dwarf shrub heathland dominated by diddle-dee Empetrum rubrum Vahl ex Willd. The Islands are home to a relatively poor native flora, comprising 171 species of vascular plants, 13 of which are endemic (Broughton \& McAdam, 2002). The main agriculture is sheep farming, which is managed on an extensive rangeland system, leaving only a few areas on the larger islands that are free from grazing pressure. Historically many of the smaller islands in the archipelago were also grazed for at least part of the year. Although this is a declining practice, particularly since the 1980s, it has greatly influenced the flora of these islands.

Despite the decline in some practices that are damaging to flora and fauna, other potentially detrimental practices have arisen with change in the economic infrastructure

D.A. Broughton ${ }^{1}$ (Corresponding author) and J.H. McAdam Department of Applied Plant Science, The Queen's University of Belfast, Newforge Lane, Belfast, BT9 5PX, Northern Ireland. E-mail: jmcadam@dardni.gov.uk

${ }^{1}$ Present address: Falklands Conservation, PO Box 26, Stanley, Falkland Islands. E-mail: fc.plants@horizon.co.fk

Received 13 June 2001. Revision requested 8 October 2001. Accepted 1 March 2002. of the islands. There is now a growing need for up-todate information on the status of the Falkland Islands wildlife. Red Data Lists can play a crucial role in meeting this need by focusing attention on species most in need of conservation action. The only published Red Data information previously available for the Falkland Islands are the international Red Data Lists (Walter \& Gillett, 1998; Hilton-Taylor, 2000). Hilton-Taylor (2000) is now the standard Red List reference, but it does not list any Falkland Islands plant species, and the most recent information available on the threatened flora of the Falkland Islands is in Walter \& Gillett (1998). This text, which uses the pre-1994 IUCN threat categories, lists six threatened species: Felton's-flower Calandrinia feltonii, hairy daisy Erigeron incertus, silvery buttercup Hamadryas argentea, fir clubmoss Huperzia fuegiana, false-plantain Nastanthus falklandicus, and rock-cress Phlebolobium maclovianum. Our aim in this paper is to provide the first comprehensive assessment of the conservation status of the Falkland Islands flora and to outline the conservation measures that have been undertaken. This is the first national Red Data List produced for any Falkland Islands taxonomic group.

\section{Methods}

We have included only those islands that comprise the Falkland Islands archipelago (including Beauchêne Island). In the past both South Georgia and the South Sandwich Islands have been administered as Dependencies of the Falkland Islands. This is no longer the case. The Falkland Islands are a geographically discrete archipelago closer to the South American mainland than to either South Georgia or the South Sandwich Islands, and represent a related but distinct phytogeographical unit with a flora 


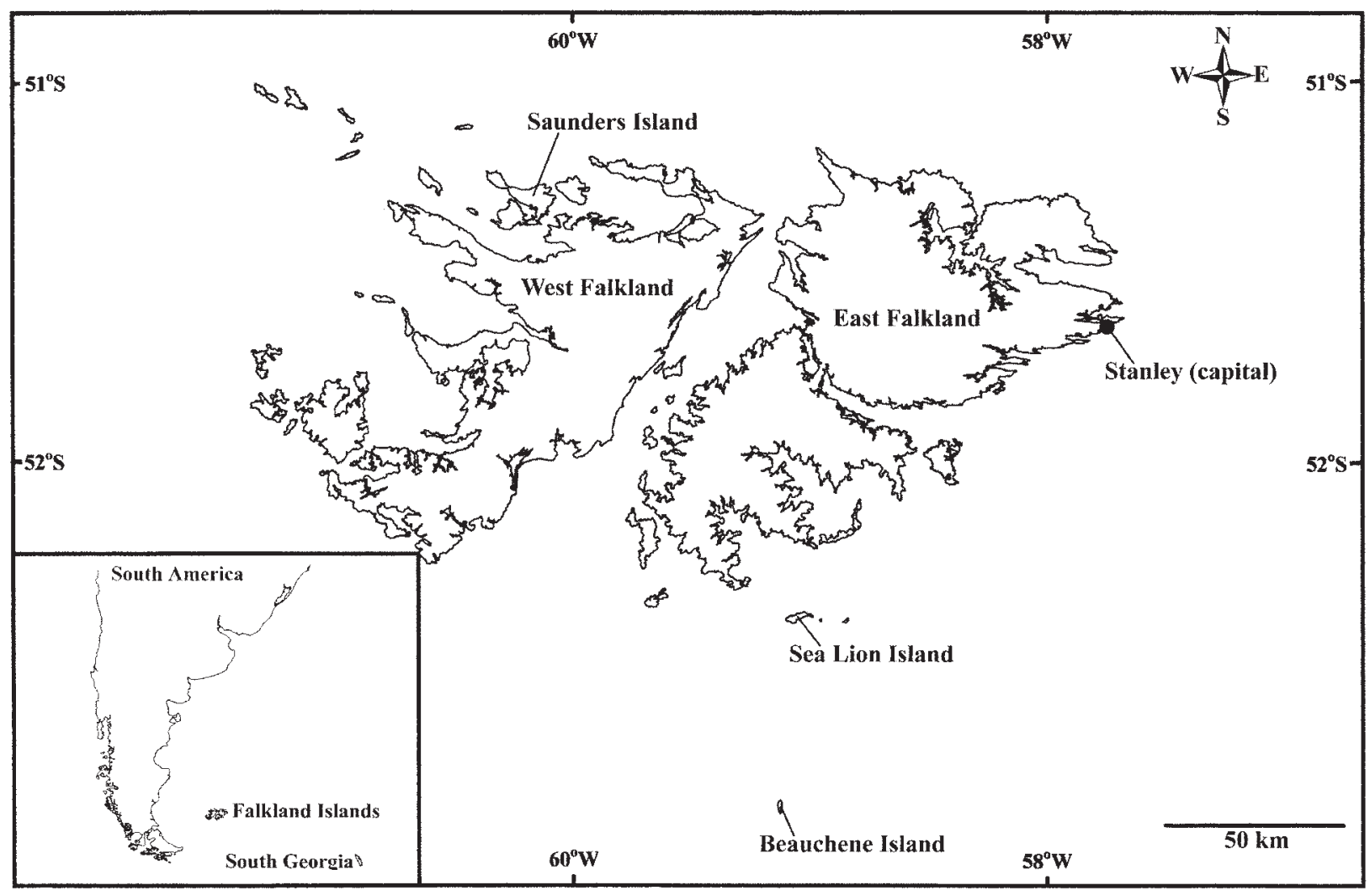

Fig. 1 The Falkland Islands archipelago, with locations mentioned in the text. Inset shows location of the Falkland Islands in relation to mainland southern South America and South Georgia.

considerably richer than that of either of these other two island groups. In consequence South Georgia and the South Sandwich Islands are outside the scope of this work.

We collected the data between September 1999 and April 2001 as part of a Darwin Initiative project to determine the status and distribution of the flora of the Falkland Islands (Broughton \& McAdam, 2002). The project involved 12 months of fieldwork spread over two field seasons. During survey work we aimed to cover as many of the Falkland Islands $10 \mathrm{~km}$ land squares (UTM Zone 21) as possible and to ensure representative geographical coverage. As a result almost $60 \%$ of grid squares were visited. Whilst we aimed to provide representative cover of $10 \mathrm{~km}$ grid squares, survey work was actually conducted by $1 \mathrm{~km}$ grid squares. We surveyed $6501 \mathrm{~km}$ grid squares and visited all the habitat types present in each square. We recorded which species were present in a particular grid square, together with information on status and ecology. Records of all plant species were deemed of equal value so that there was no intentional bias towards any particular group. Data was also obtained from previous surveys (Broughton et al., 2000), herbarium specimens and the literature (Skottsberg, 1913; Moore, 1968, 1973). The compiled information was entered into a database and comprises 26,121 individual records; it was these data that were used to produce the Red List. Further details on survey methodology and the database are available from the authors.

All 171 species native to the Falkland Islands were assessed for inclusion in the Red List using the most recent (version 3.1) IUCN Red List categories and criteria (IUCN, 2001) and with reference to Gärdenfors et al. (2001). The national Red Data List includes all vascular plant species that are nationally threatened and, for completeness, it also includes Near Threatened and Data Deficient taxa. The species listed range from those that are endemic to the Falkland Islands to those that are globally more widespread and common.

\section{Results}

This first National Red List for the Falkland Islands flora contains 33 plant species (Table 1). This is $19 \%$ of the native species, of which 23 species $(13 \%)$ are nationally threatened (Table 2). The remainder consists of three Near Threatened species (2\%) and seven Data Deficient species (4\%). Six Least Concern species are also included in Table 1 because they are endemic to the Falkland Islands. 


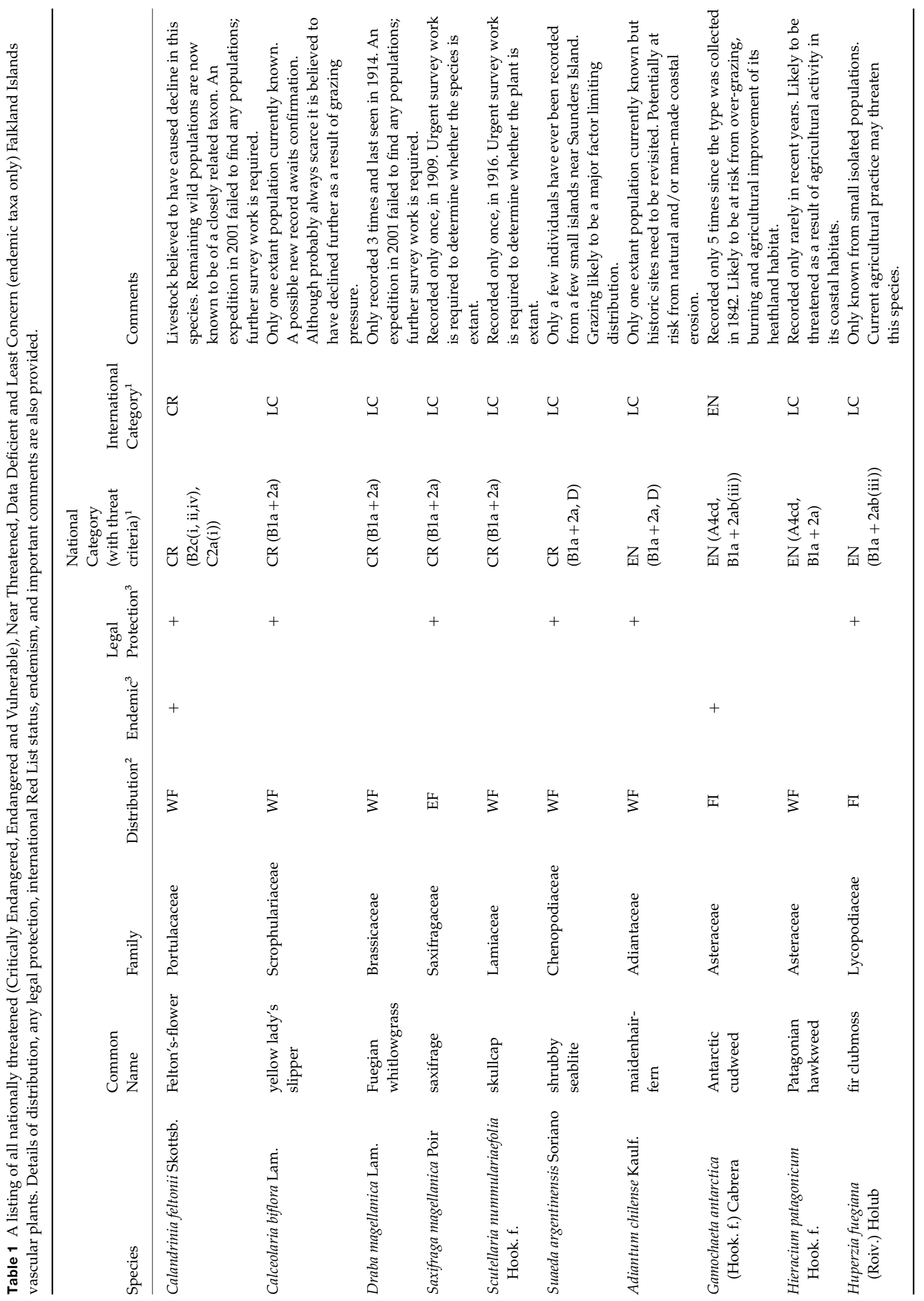

(C) $2002 \mathrm{FFI}$, Oryx, 36(3), 279-287 


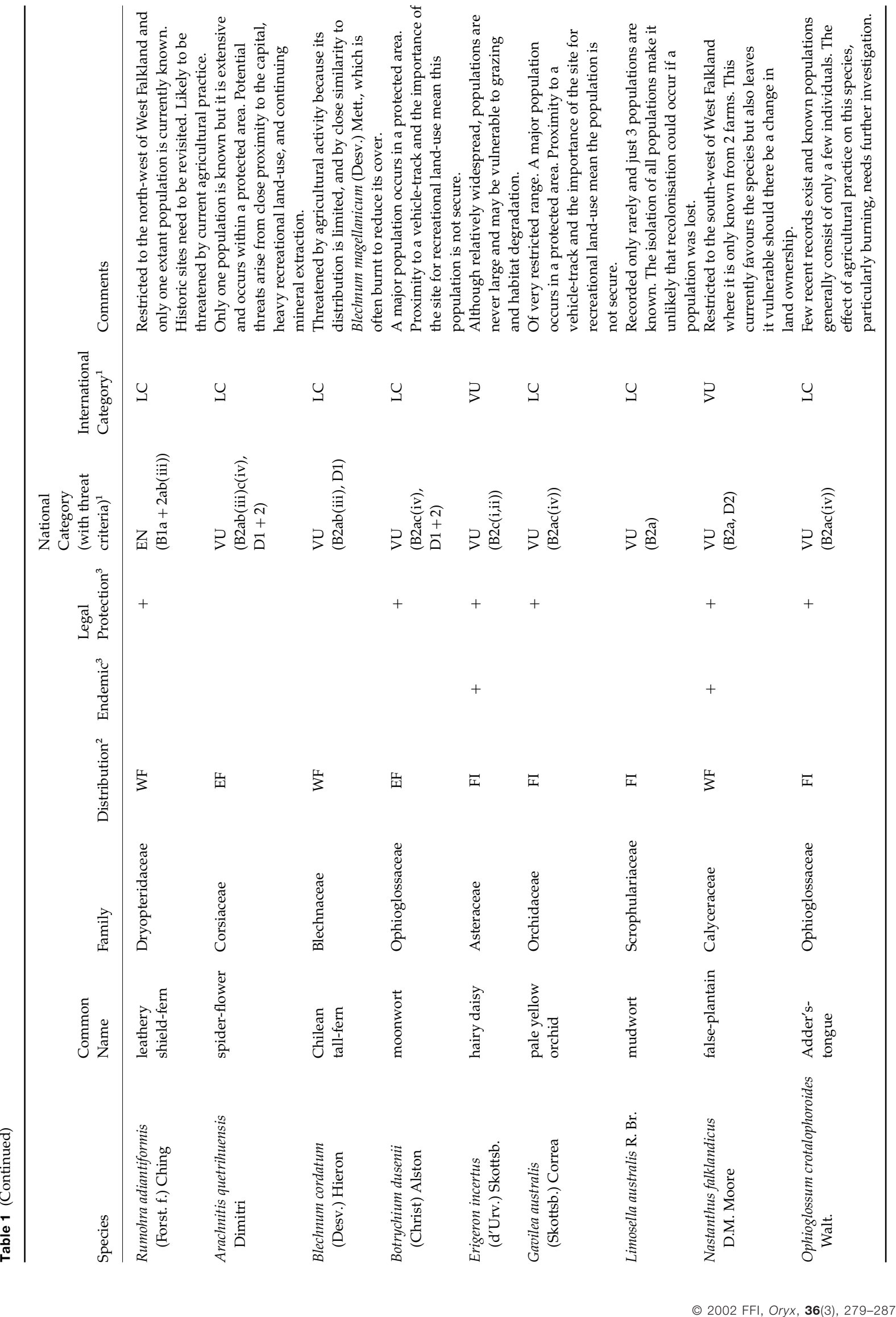




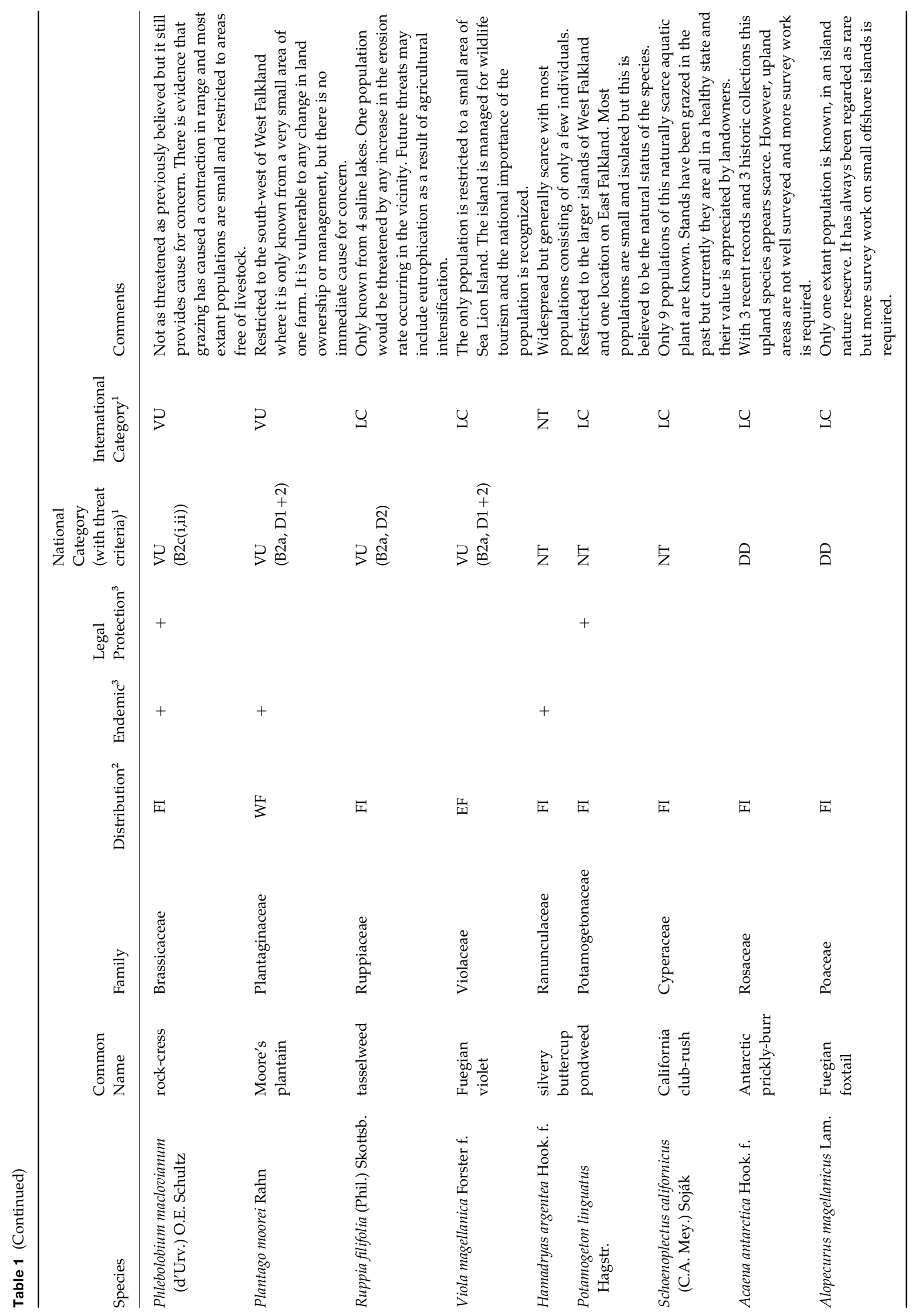




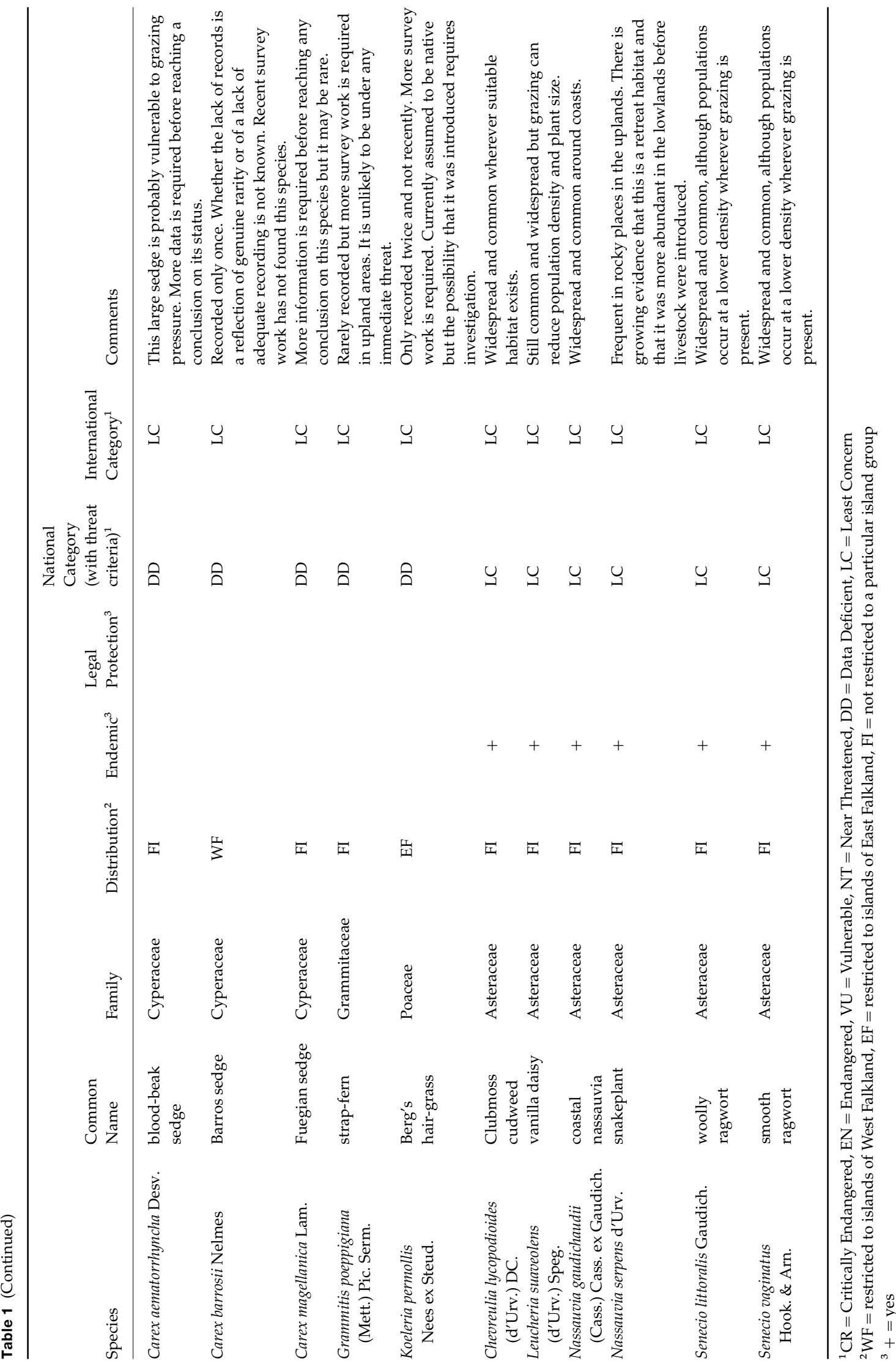


Table 2 Summary of the nationally and internationally Extinct, threatened (Critically Endangered, Endangered and Vulnerable), Near Threatened, Data Deficient and Least Concern flora of the Falkland Islands, expressed in terms of total number of species and as a percentage of the native flora.

\begin{tabular}{|c|c|c|c|c|c|c|c|c|}
\hline & \multicolumn{7}{|c|}{ IUCN Red List category } & \multirow[b]{2}{*}{ Total } \\
\hline & EX & CR & EN & VU & NT & DD & LC & \\
\hline $\begin{array}{l}\text { National totals } \\
\text { (\% of native flora) }\end{array}$ & $\begin{array}{l}0 \\
(0 \%)\end{array}$ & $\begin{array}{c}6 \\
(3 \%)\end{array}$ & $\begin{array}{l}5 \\
(3 \%)\end{array}$ & $\begin{array}{l}12 \\
(7 \%)\end{array}$ & $\begin{array}{l}3 \\
(2 \%)\end{array}$ & $\begin{array}{l}7 \\
(4 \%)\end{array}$ & $\begin{array}{l}139 \\
(81 \%)\end{array}$ & 171 \\
\hline $\begin{array}{l}\text { International totals } \\
\text { (\% of native flora) }\end{array}$ & $\begin{array}{c}0 \\
(0 \%)\end{array}$ & $\begin{array}{l}1 \\
(0.6 \%)\end{array}$ & $\begin{array}{l}1 \\
(0.6 \%)\end{array}$ & $\begin{array}{l}4 \\
(2 \%)\end{array}$ & $\begin{array}{l}1 \\
(0.6 \%)\end{array}$ & $\begin{array}{c}0 \\
(0 \%)\end{array}$ & $\begin{array}{l}164 \\
(96 \%)\end{array}$ & 171 \\
\hline
\end{tabular}

Of the threatened taxa, six are Critically Endangered (26\% of threatened plants), five are Endangered (22\%) and 12 are Vulnerable (52\%). Eleven threatened plant species $(48 \%)$ are restricted to the islands of West Falkland and four $(17 \%)$ to the islands of East Falkland. The remaining 8 threatened species (35\%) are more generally distributed across the archipelago. Six nationally threatened species (26\%) are endemic to the Falkland Islands. Only six of the Falkland Island species (26\% of nationally threatened taxa) have been categorized as threatened internationally, all of them Falkland Islands' endemics.

\section{Discussion}

In comparison with other South American countries, the Falkland Islands have an extremely impoverished flora, comprising 171 native species (Broughton \& McAdam, 2002). Many species are at the eastern and southern limits of their range in the Falkland Islands, and thus many of the rare taxa occur more abundantly in other parts of South America and the world. This does not detract from their value in the Falkland Islands nor internationally. Species at or near the limit of their geographical range are close to their tolerance for environmental factors and they develop locally adapted populations (ecotypes), which may be genetically or physiologically distinct from populations elsewhere (Wigginton, 1999). There is a need to conserve such diversity, and the importance of conserving the full extent of a species natural range is reflected in the IUCN threat criteria and should be a key objective in conserving Falkland Islands biodiversity.

Some of the taxa categorized as threatened have probably always been relatively rare, such as a component of the flora that is restricted to the north-west of West Falkland. However, since the introduction of livestock these taxa have decreased in frequency of occurrence and distribution, along with other species that would have been more abundant and widespread in the past (McAdam, 1996). No Falkland Islands species has yet been proven, beyond reasonable doubt, to be extinct. But there are no recent records for four species: Fuegian whitlowgrass Draba magellanica, Felton's-flower Calandrinia feltonii, saxifrage Saxifraga magellanica, and skullcap Scutellaria nummulariaefolia. Survey work is urgently required to determine whether they are Critically Endangered, as categorized in this paper, or nationally extinct. Recent surveys for the Felton's-flower and the Fuegian whitlowgrass did not identify any populations, but more survey work is required.

For many of the other threatened taxa the situation, up until recently, has been less urgent. Although they are often extremely rare, and although agricultural activity has probably been the main cause of the decline in these species, long-term conformity in agricultural practice has allowed small remnant populations to persist. This is no longer the case. There is a pressing need to diversify the rural and national economies, and since the early 1980s agricultural practice, and the economic infrastructure of the Falkland Islands, has been undergoing rapid change. The flora is now under ever increasing pressure from agricultural diversification and intensification, including widespread pasture improvement programmes, and to a lesser extent from the current road-building programme. Other important threats include a general ignorance about the native flora, including the rare and threatened species, within the Falkland Islands, a lack of detailed data on which to base development and land-management decisions, and an inadequate Environmental Impact Assessment process for proposed developments.

Internationally the conservation of endemic Falkland Islands taxa is perhaps of greatest importance, and should be the focus of priority action. Thirteen species ( $8 \%$ of the native flora) are endemic to the Falkland Islands archipelago (Table 1$)$. Six of these $(46 \%$ of endemics) are threatened ( $26 \%$ of threatened plants) and one is Near Threatened. Of the threatened endemic plants, the Felton's-flower is Critically Endangered, the Antarctic cudweed Gamochaeta antarctica is Endangered, and the other four species are Vulnerable. 
Conservation programmes should also include those taxa for which the Falkland Islands have an international responsibility because a high proportion of the world population occurs there. Two such taxa are nearendemic, the Falkland cudweed Gamochaeta malvinensis (H. Koyama) T. R. Dudley and the shield-fern Polystichum mohrioides (Bory) C. Presl. (Broughton \& McAdam, 2002). Populations of the tussac-grass Poa flabellata (Lam.) Hook. f. are also important because this species is restricted to the southern tip of South America, the Falkland Islands and some subantarctic Islands. Although the Falkland Islands populations of these taxa are important, none qualify for inclusion in the present Red Data List. However, the populations should be monitored and their status assessed from time to time.

Some of the threatened flora is of interest because it is restricted to a particular part of the archipelago. These species have small native ranges and so are often of greatest conservation concern and make up the greatest proportion of threatened species. West Falkland exhibits this most noticeably; it has 11 threatened plant species ( $48 \%$ of the threatened flora) that are found nowhere else in the archipelago, including the false-plantain Nastanthus falklandicus and Moore's plantain Plantago moorei, both 'narrow' endemics. Four threatened plants $(17 \%)$ are restricted to East Falkland, and the remaining eight threatened taxa $(35 \%)$ are not restricted to a particular island group.

The first legislation affording significant protection to certain wild plant species was enacted in 1999 (FIG, 1999). This legislation gave protection to 18 taxa that were assessed to be most threatened (Table 1). One other species, the common violet Viola maculata Cav., was also protected, as it is believed to be the larval food-plant of a nationally threatened butterfly species (Issoria cytheris Drury). At the time of designation few quantitative data were available on the status and distribution of species and, as a consequence, several threatened taxa were not protected. At the same time, other species that are not threatened, such as Gaudichaud's orchid Chloraea gaudichaudii Brongn., yellow orchid Gavilea littoralis (Phil.) M. N. Correa and the yellow maiden Sisyrinchium chilense Hook, were given legal protection. The combfern Schizaea fistulosa Labill., a species no longer believed to have occurred in the Falkland Islands (Skottsberg, 1913; Broughton, 2000), was also given unnecessary protection. These four protected species are therefore not included on the Red List presented here.

Under the legislation (FIG, 1999) it is an offence to intentionally pick, collect, cut, uproot or destroy a protected wild plant. It is also an offence to trade any live or dead plant, and its derivatives. Threatened plants, protected or otherwise, also benefit from provisions in the legislation relating to the designation of National
Nature Reserves and the making of regulations to prohibit the picking or uprooting of any plant growing within a designated reserve. Instead of being designated as statutory reserves, private land may also be declared a wildlife reserve by the owner. A number of such private reserves exist, but because the sensitivity with which they are managed lies entirely in the hands of the relevant landowners they are not all of equal conservation value. As a consequence private reserves may not be managed to provide the maximum benefit to threatened plant species. The only international Convention currently relevant to the Falkland Islands flora is CITES and the Convention is only applicable to the four Falkland Islands members of the Orchidaceae, only one of which is threatened. All orchids are covered by Appendix II of the Convention, which lists those taxa whose international trade is subject to control.

The conservation of wild flora in the Falkland Islands is still in its early stages and has advanced little beyond initiatives to purchase nature reserves. However, with an increase in public awareness and interest in conservation issues, fuelled to some degree by land reform and the increased role of tourism in the economy, there are signs of a shift in focus from protecting sites of high wildlife value to direct action to address conservation problems, such as a trial reintroduction of the Felton'sflower. In particular, there is a slowly growing awareness of the need to protect and manage threatened plants outside nature reserves and protected sites. This will be vital because most of the species on the Red List are not well represented in the current framework of protected areas. Thus, land-managers whose prime concern is other than with nature conservation may have a significant responsibility in ensuring the continued survival of threatened plant species.

The slow start in addressing plant conservation should not just be attributed to limited resources or lack of political willpower. A major hindrance has previously been the lack of detailed baseline data and a lack of botanical expertise within the Falkland Islands. This need has now begun to be addressed with a Darwin Initiative funded project (Broughton \& McAdam, 2002), the establishment of a national herbarium, and the production of a new field guide (Woods, 2000), and it is to be hoped that further progress will follow.

In conclusion, whilst agriculture and development have been identified as major factors in the decline of some elements of the native flora, it is also possible to implicate a general ignorance of the native Falkland Islands flora and its importance. Given the small size of the Falkland Islands human population, there is scope for halting and reversing the decline of threatened flora. However, this will be dependent on the provision of sufficient resources. Steps have already been taken with 
the aid of Darwin Initiative funding, but increased public awareness is still required. In addition, regular monitoring of threatened plant populations is required along with investigations of their biology and the reasons for their decline, and all threatened taxa not currently protected need to be afforded full legal protection. Also, given the importance of conserving genetic diversity (Wigginton, 1999; Lesica \& Allendorf, 1995), the genetic aspects of rare plant conservation require greater attention. This will only be achievable when the commitment of the under-resourced NGO sector is matched by a greater commitment of the Falkland Islands Government to meet its statuary obligations in terms of plant research and conservation.

\section{Acknowledgements}

This work would not have been possible without funding from the UK Government through the Darwin Initiative (Department for Environment, Food and Rural Affairs), and the involvement of the projects local partners, Falklands Conservation. The support of Tom Eggeling (Environmental Planning Officer, Falkland Islands Government) is also gratefully acknowledged.

\section{References}

Broughton, D.A. (2000) A note on the status of Comb-fern in the Falkland Islands. The Falkland Islands Journal, 7, 1-2.

Broughton, D.A. \& McAdam, J.H. (2002) The Vascular Flora of the Falkland Islands: An Annotated Checklist and Atlas. Unpublished report to Falklands Conservation.

Broughton, D.A., McAdam, J.H. \& Brännström, R. (2000) A combined checklist and ecogeographic conspectus for the vascular flora of Saunders Island, Falkland (Malvinas) Islands. Anales del Instituto del la Patagonia, Serie Ciencias Naturales, 28, 57-88.

FIG (1999) Conservation of wildlife and nature ordinance 1999. The Falkland Islands Gazette Supplement, 10, 2-18.

Gärdenfors, U., Hilton-Taylor, C., Mace, G. \& Rodríguez, J.P. (2001) The application of IUCN Red List criteria at regional levels. Conservation Biology, 15, 1206-1212.

Hilton-Taylor, C. (2000) 2000 IUCN Red List of Threatened Species. IUCN, Gland, Switzerland and Cambridge, UK. IUCN (2001) IUCN Red List Categories and Criteria: Version 3.1. IUCN, Gland, Switzerland and Cambridge, UK.
Lesica, P. \& Allendorf, F.W. (1995) When are peripheral populations valuable for conservation? Conservation Biology, 9, 753-760.

McAdam, J.H. (1985) The effect of climate on plant growth and agriculture in the Falkland Islands. Progress in Biometeorology, 2, 155-176.

McAdam, J.H. (1996) The current status, threats to and conservation of the flora of the Falkland Islands. Aspects of Applied Biology, 44, 419-424.

Moore, D.M. (1968) The vascular flora of the Falkland Islands. British Antarctic Survey Scientific Reports, 60, 1-202.

Moore, D.M. (1973) Additions and amendments to the vascular flora of the Falkland Islands. British Antarctic Survey Bulletin, $32,85-88$.

Skottsberg, C. (1913) A botanical survey of the Falkland Islands. Kungliga Svenska Vetenskapsakademiens Handlingar, 50, $1-129$.

Walter, K.S. \& Gillett, H.J. (eds) (1998) 1997 IUCN Red List of Threatened Plants. IUCN, Gland, Switzerland and Cambridge, UK.

Wigginton, M.J. (1999) British Red Data Books 1. Vascular plants. JNCC, Peterborough, UK.

Woods, R.W. (2000) Flowering plants of the Falkland Islands. Falklands Conservation, London.

\section{Biographical sketches}

David Broughton began his involvement with the Falkland Islands as a postgraduate at Queen's University, researching their dwarf shrubs and shrub heathlands. He then spent two summers in the Islands running a Darwin Initiative project investigating the status and distribution of the wild flora. In October 2001 he began work as Conservation Botanist at Falklands Conservation and is the first botanist employed by the organisation.

Jim McAdam began his involvement with the Falklands in 1976 as Agronomy Officer in the Grassland Trials Unit. He currently works in the Science Service of the Department of Agriculture and Rural Development, Northern Ireland and lectures at Queen's University. He maintains an active involvement in Falklands research, is a consultant to the UK Falkland Islands Trust, and acts as advisor to the Falklands Department of Agriculture. His other research interests include agroforestry, rural development, and the ecology and management of heathland and cool-temperate grasslands. 